\title{
Rising Income Inequality, Increased Household Indebtedness, and Post-Keynesian Macrodynamics*
}

Mark Setterfield ${ }^{\dagger}$

\begin{abstract}
A Kaleckian growth model is modified to incorporate working households who borrow to finance some part of their consumption spending. The impact of this behavior on the sustainability of the growth process is then studied by means of a numerical analysis that captures various dimensions of increased income inequality in the US. The results show that the precise manner in which debtor households service their debts has important effects on the economy's macrodynamics.
\end{abstract}

Keywords: Consumer debt. Emulation. Income distribution. Golden Age growth regime. Neoliberal growth regime.

\section{JEL Classification: E12, E44, O41.}

\section{Introduction}

A substantial literature connects the relatively rapid growth of the US economy during the Great Moderation to aggressive increases in household indebtedness that offset the other-wise negative impact on consumption spending of increased income inequality (Palley, 2002; Cynamon and Fazzari, 2008; Barba and Pivetti, 2009; Wisman, 2013; Setterfield, 2013). But did these same forces create a source of increasing financial fragility that were contributory to the Great Recession and its aftermath? This question is investigated in what follows by examining the impact of increased income inequality and household debt servicing behavior on the sustainability of the Neoliberal (1980-2007) growth regime in the US. In the course of this analysis we explore further a key hypothesis of Setterfield and Kim (2013), that not only debt servicing per se but the precise manner in which debtor households service their debts affects the macrodynamics of a PostKeynesian economy.

The remainder of the paper is organized as follows. Section 2 describes the basic model. Section 3 explores the impact of changes in inequality and debt servicing behavior on the sustainability of the growth process by means of a numerical analysis. The fourth section concludes.

\section{Model Structure and Short-Run Solution}

The model is based on the work of Setterfield and Kim (2013) and Setterfield et al. (2014), to which the reader is referred for further detail and discussion. It consists of banks, firms, and two

\footnotetext{
* This paper draws on material from Setterfield and Kim (2013) and Setterfield et al. (2014) presented at the VII Encontro Internacional da Associação Keynesiana Brasileira (AKB), Fundação Getúlio Vargas, Escola de Economia de São Paulo (EESP), August 13-15, 2014. I would like to thank the Institute for New Economic Thinking for generous financial support that facilitated work on this paper.

${ }^{\dagger}$ New School For Social Research and Trinity College, Hartford; setterfm@newschool.edu.
} 
types of households - working households who borrow to finance some part of their current consumption and rentier households who do not. Because our focus is on household behavior, firms and banks are highly simplified. Firms produce, set prices, and invest in standard Kaleckian fashion, their investment expenditure funded entirely by capitalists who purchase equities. Banks, meanwhile, act as passive intermediaries between debtor and creditor households, earning no income and accumulating no net worth.

Total income in the economy is given by:

$$
Y=W_{p} N+W_{r} \alpha N+\Pi
$$

where $Y$ denotes real income, $\Pi$ denotes total real profits, $W_{p}$ is the real wage of production workers, $W_{r}$ is the real wage of supervisory workers, $N$ is the number of production workers employed, and $\alpha<1$ denotes the necessary ratio of managers to production workers (given by technology and the organizational structure of the production process). In equation (1) and following Palley (2013), $W_{p} N$ is the income of working (net debtor) households and $W_{r} \alpha N+\Pi$ is the income of rentier (net creditor) households, the latter made up of capitalists and supervisory workers. The fixed real wage earned by production workers is assumed to be a fraction of the real wage of managers, or:

$$
W_{r}=\varphi W_{p}
$$

where $\varphi>1$. Total real wage income is then:

$$
\begin{gathered}
W=W_{p} N+W_{r} M \\
\Rightarrow W=W_{p} N+\varphi W_{p} \alpha N=(1+\varphi \alpha) W_{p} N
\end{gathered}
$$

Denoting production workers' wage share of total income as $\omega_{p}$ and managers' wage share as $\omega_{r}$, it follows that:

$$
\omega_{r}=\varphi \alpha \omega_{p}
$$

Note, then, that on the basis of equations (1) and (4):

$$
\begin{aligned}
1-\pi & =(1+\varphi \alpha) \omega_{p} \\
\Rightarrow^{\omega} p & =\frac{1-\pi}{1+\varphi \alpha}
\end{aligned}
$$

where $\pi=\Pi / Y$ is the gross profit share.

Following Stockhammer (1999), firms' desired investment rate $\left(g_{K}=I / K\right)$ is described as:

$$
g_{K}=\kappa_{0}+\kappa_{r} r
$$


where $r=\Pi / K$ is the rate of profit. Since $r$ is the product of the profit share and the capacity utilization rate $(u=Y / K)$, equation (6) can be re-written as:

$$
g_{K}=\kappa_{0}+\kappa_{r} \pi u
$$

Finally, aggregate consumption by households (C) is written as:

$$
C=C_{W}+C_{R}+\dot{D}
$$

where $C_{W}$ and $C_{R}$ are consumption from current income by workers and rentiers, respectively, and $D$ is borrowing by working households. The individual components of equation (8) are then modeled as follows. First, we describe consumption by rentiers as a fixed proportion of their total wage, profit, and interest income:

$$
\left.C_{R}=c_{\pi}\left[W_{r} \alpha N+\Pi+i D_{R}\right)\right]
$$

where $i$ denotes the real interest rate and $D_{R}$ is the net debt owed by working households to rentiers ${ }^{1}$. Consumption spending by workers, meanwhile, is made up of two components. First, consumption financed by borrowing is characterized as:

$$
\dot{D}=\beta\left(C^{T}-C_{W}\right), \beta>0
$$

where $C^{T}$ denotes a target level of consumption to which working households aspire, specified as:

$$
C^{T}=\eta C_{R}
$$

The adjustment parameter $\beta$ in equation (10) depends on household borrowing norms and financial market lending norms, and is taken as given ${ }^{2}$. In equation (11), workers attempt to emulate rentier consumption. The larger the emulation parameter $\eta$, the higher the target level of consumption $C^{T}$ in equation (11) and the more debt financed consumption is undertaken by workers in equation (10).

The second component of workers' consumption is consumption spending funded by current income. In Setterfield and Kim (2013):

$$
C_{W}=c_{W} W_{p} N
$$

and:

$$
S_{W}=\left(1-c_{W}\right) W_{p} N-i D_{R}
$$

In other words, workers' behavior conforms to a distinct hierarchy or "pecking order", according to which they first consume from current income, then service their debts, and finally

\footnotetext{
${ }^{1}$ Rentier households fund only part of the debt accumulated by working households: the remainder is funded by other working households, who are assumed to save even as they borrow.

${ }^{2}$ Unlike Dutt $(2005,2006)$, we do not explicitly model a constraint on workers' borrowing arising from the preferences of lenders. As is clear form the definition of $\beta$, however, borrowing by workers is constrained by rentier behavior. For example, rentier concerns about the credit-worthiness of working households will decrease $\beta$ and reduce workers' borrowing, ceteris paribus.
} 
treat saving as a residual determined by prior consumption and debt servicing outlays. Alternatively, we could write:

$$
C_{W}=c_{W}\left(W_{p} N-i D_{R}\right)
$$

so that:

$$
S_{W}=\left(1-c_{W}\right)\left(W_{p} N-i D_{R}\right)
$$

This involves a more conventional treatment of debt servicing as an initial deduction from income, the remainder of which is then either consumed or saved.

Regardless of how workers choose to service their debts, goods market equilibrium can be stated as:

$$
Y=C_{W}+C_{R}+\dot{D}+I
$$

where $I=g_{K} K$ denotes total investment spending by firms. By substituting equations (9), (10), and (12) into this equilibrium condition, normalizing all variables by the capital stock, and utilizing equations (5) and (7), equation (16) can be solved for the short-run rate of accumulation:

$$
g_{K}=\kappa_{0}+\frac{\kappa_{r} \pi\left[\kappa_{0}+i d_{R} c_{\pi}(1+\beta \eta)\right]}{\left\{1-\left[c_{\pi}(1+\beta \eta)+\kappa_{r}\right] \pi-\frac{[1-\pi]\left[c_{m}(1-\beta)+c_{\Pi}(1+\beta \eta) \varphi \alpha\right]}{1+\varphi \alpha}\right\}}
$$

The term $d_{R}=D_{R} / K$ in equation (17) is workers' net debt (i.e., debt owed to rentiers) to capital stock ratio. This bears a straightforward relationship to the more intuitive debt to income ratio, which is given by $D_{R} / W p N=d_{R} / \omega_{p} u$. Employing the solution method outlined above, but using equation (14) in place of equation (12), yields:

$$
g_{K}=\kappa_{0}+\frac{\kappa_{r} \pi\left[\kappa_{0}+i d_{R}\left(c_{\pi}[1+\beta \eta]-c_{w}[1-\beta]\right)\right]}{\left\{1-\left[c_{\pi}(1+\beta \eta)+\kappa_{r}\right] \pi-\frac{[1-\pi]\left[c_{w}(1-\beta)+c_{m}(1+\beta \eta) \varphi \alpha\right]}{1+\varphi \alpha}\right\}}
$$

\section{Did Increasing Inequality Undermine the Neoliberal Growth Regime in the US?}

The question addressed in this section is whether or not long-run steady-state growth is financially sustainable, given the assumptions made about workers' debt servicing behavior and the historical changes in income inequality that accompanied the transition to the Neoliberal growth regime in the US. Note that from the definition of $d_{R}$, it follows that:

$$
d_{R}=\frac{\beta\left({ }_{C} T_{-} C_{W}\right)-D_{W}}{K}-g_{K} d_{R}
$$




$$
=\frac{\beta\left(\eta C_{R}-C_{W}\right)-\dot{D_{W}}}{K}-g_{K} d_{R}
$$

Using equation (12), equation (19) can be solved as:

$$
\dot{d}_{R}=\beta \eta c_{\pi}\left(\omega r u+\pi u+i d_{R}\right)-\left(1+\beta c_{W}-c_{W}\right) \omega p u+i d_{R}-g_{K} d_{R}
$$

whereas using equation (14), equation (19) becomes:

$$
\dot{d}_{R}=\beta \eta c \pi\left(\omega r u+\pi u+i d_{R}\right)-\left(1-[1-\beta] c_{W}\right)\left(\omega p u-i d_{R}\right)-g_{K} d_{R}
$$

Setterfield et al. (2014) show that for the parameter values reported in Table 1 below, equation (21) takes the conventional $\mathrm{u}$-shape form depicted in Figure 1 and found elsewhere in the literature (see, for example, Hein (2012, pp.94-98)). In this case, the smaller of the two roots of equation (21), denoted by $d_{R 2}$ in Figure 1, will correspond to the stable steady state solution of this equation. Meanwhile, Setterfield and Kim (2013) show that equation (20) always conforms to the inverse u-shape depicted in Figure 2, which implies that the larger of the two roots of equation (20), denoted by $d_{R l}$ in Figure 2, will now correspond to the stable steady state solution of the equation.

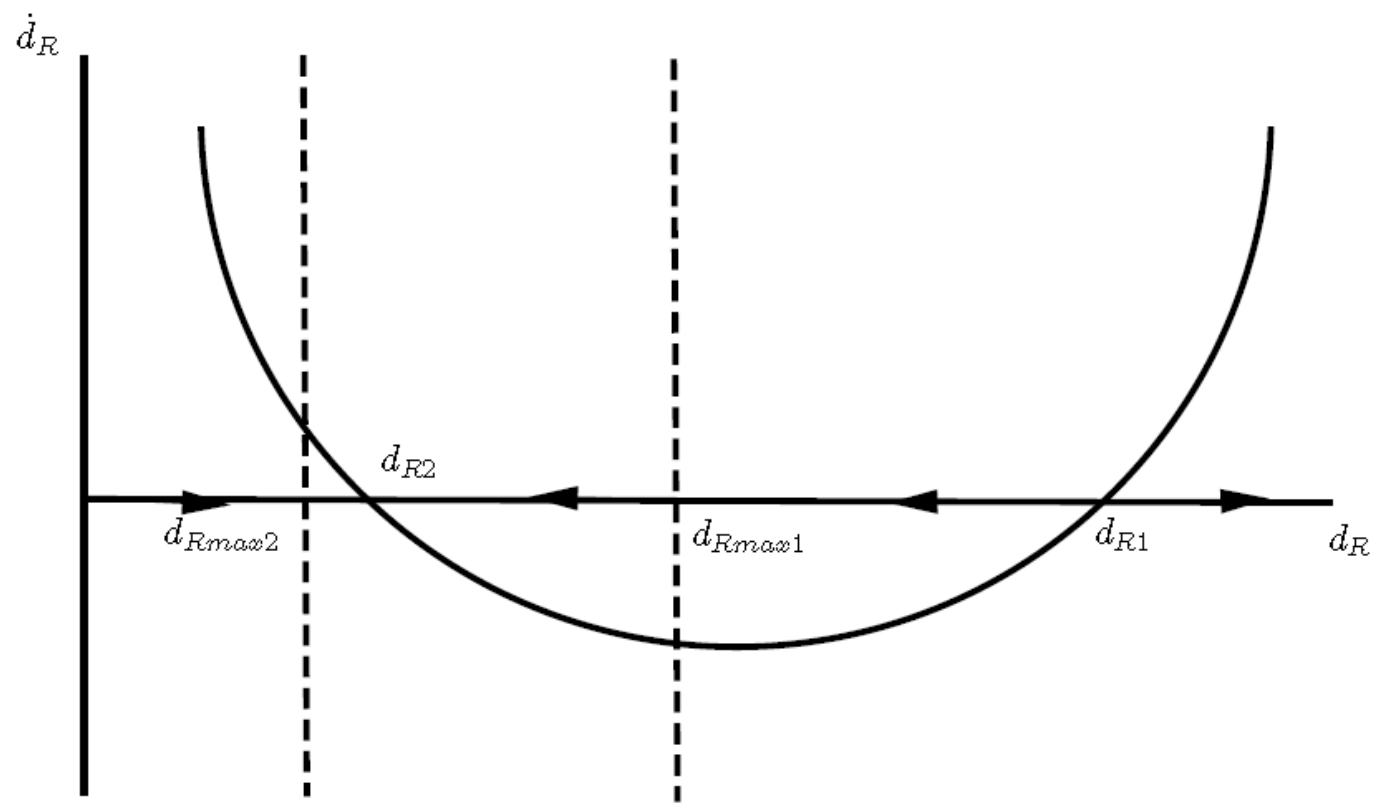

Figure 1: Debt dynamics: the "conventional" case

The significance of these observations becomes evident when we consider the proximity of the stable steady state value of $d_{R}$ to the maximum feasible net debt to capital ratio of working households, $d_{R \max }$. This allows us to reect on the sustainability of the growth process. First note that from our description of workers' consumption and debt servicing behavior in equation (12), we can define a feasibility coefficient:

$$
c=\left(1-c_{W}\right) \omega_{p} u-i d_{R}
$$


that must satisfy $c \geq 0$ in order for working households to continue servicing their debts. The equivalent feasibility condition derived from equation (14) is:

$$
c=\omega_{p} u-i d_{R}
$$

In either case, the value of $d_{R \max }$ is revealed by setting $c=0$ and solving for $d_{R}$. If our debt dynamics are conventional as in Figure 1 (where $d_{R 2}$ is the stable, steady-state debt to capital ratio), then with $d_{R \max }=d_{R \max }, d_{R} \leq d_{R \max 1}$ initially suffices to ensure that convergence to $d_{R 2}$ is feasible. The accompanying steady-state growth rate will then be sustainable indefinitely (ceteris paribus). Only if $d_{R \max }$ is very low - as exemplified by $d_{R \max 2}$, for instance - will the growth process be unsustainable. But now consider Figure 2, where $d_{R l}$ is the stable equilibrium. A much higher value of $d_{R \max }$ is required in Figure 2 to guarantee the sustainability of the growth regime.

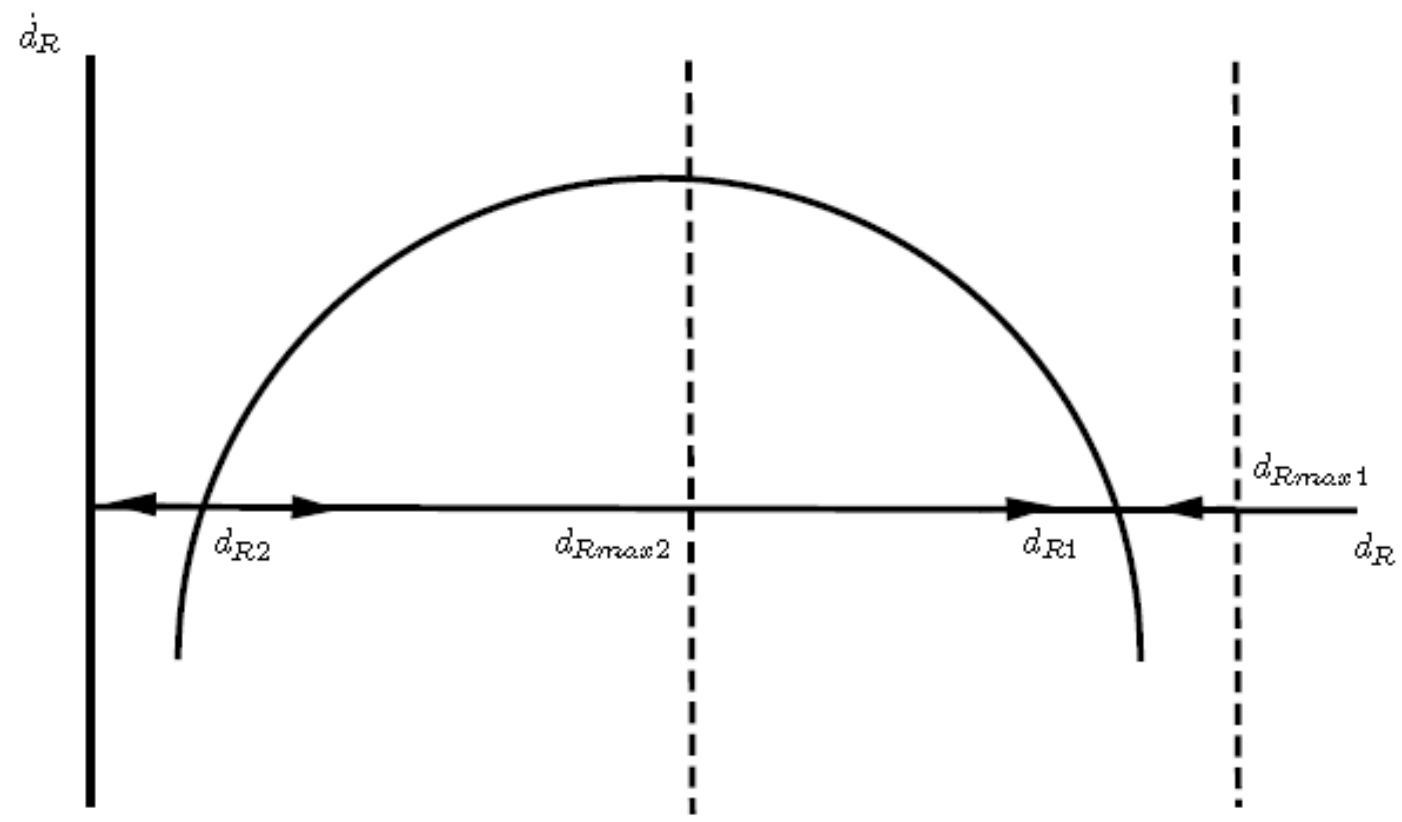

Figure 2: Debt dynamics: the "unconventional" case

The parameter values in Table 1 allow us to identify more concretely the proximity of $d_{R \max }$ to the steady-state value of $d_{R}$ - as refected by $c \gtrless 0$ - given the observed distributional characteristics of the Neoliberal growth regime and the assumptions made about debt servicing behavior ${ }^{3}$.

\footnotetext{
${ }^{3}$ Following Setterfield and Kim (2013), the propensity of working households to emulate rentier consumption, $\eta$, is calculated as $\eta=\lambda \delta$, where $\lambda$ is the emulation parameter calculated by Ravina (2007) and $\delta$ is a "scaling parameter" that captures the ratio of consumption by the upper-middle class to that of the median rentier family, proxied by the ratio of CEO pay to household income at the $90^{\text {th }}$ percentile of the size distribution of income. Assuming that emulation
} 
As previously noted, the likelihood that the growth regime will prove sustainable is increased if the economy's debt dynamics are conventional. The sustainability of the growth process is explored in Tables 2 and 3, which report the values of both roots of equation (19), $d_{R l}$ and $d_{R 2}$, the maximum debt to capital ratio that can be sustained by working households $\left(d_{R \max }\right)$, and the feasibility coefficient, $c$ (evaluated at the stable steady state value of $d_{R}$ ) under different assumptions about the debt servicing behavior of workers.

Table 2 suggests that all other things equal, the distributional changes wrought by the transition from the Golden Age (1945-73) to the Neoliberal growth regime in the US were sufficient to render the growth process in the US unsustainable $(c>0$ during the Golden Age but $c<0$ for the Neoliberal regime $)^{4}$. Note, however, that this result assumes the behavior described in equation (12), which renders the economy's debt dynamics unconventional (Figure 2). According to Table 3, the same distributional changes are revealed as insufficient to render growth unsustainable $(c>0$ for both the Golden Age and Neoliberal regimes) as long as workers behave in accordance with equation (14) and the economy's debt dynamics are conventional (Figure 1).

\section{Table 1: Parameter values}

\begin{tabular}{|c|c|c|}
\hline Parameter & Value & Source \\
\hline$c_{W}$ & 0.94 & $\begin{array}{c}\text { Authors' calculations based on } \\
\text { Bunting (1998) }\end{array}$ \\
\hline$c_{\pi}$ & 0.20 & Setterfield and Budd (2011) \\
\hline$\beta$ & 0.10 & Authors' calculations ${ }^{1}$ \\
\hline$\lambda$ & 0.29 & Ravina(2007) \\
\hline$\delta$ & 74.89 & $\begin{array}{l}\text { Authors' calculations based on } \\
\text { Mishel and Sabadish (2012) and } \varphi\end{array}$ \\
\hline$\varphi$ & 2.27 & $\begin{array}{c}\text { Authors' calculations based on } \\
\text { Mishel et al.(2007) }\end{array}$ \\
\hline$\alpha$ & 0.25 & Authors' calculations ${ }^{2}$ \\
\hline$\omega_{p}$ & 0.42 & $\begin{array}{c}\text { Authors' calculations based on } \\
\text { Mohun (2006), Figure7 }\end{array}$ \\
\hline$\pi$ & 0.34 & Authors' calculations ${ }^{3}$ \\
\hline$\kappa_{0}$ & 0.095 or 0.045 & Authors' calculations 4 \\
\hline$\kappa_{r}$ & 0.5 & $\begin{array}{l}\text { Lavoie and Godley (2001-02), } \\
\text { Skott and Ryoo (2008) }\end{array}$ \\
\hline$i$ & 0.0481 & $\begin{array}{c}\text { Authors' calculations based on } \\
\text { World Bank Data }\end{array}$ \\
\hline
\end{tabular}

in consumption is ultimately driven by the consumption spending of the upper-middle class (Levine et al., 2010), this formulation makes the emulation parameter, $\eta$, sensitive to changes in income inequality within the rentier class.

${ }^{4}$ The values of the Golden Age distributional parameters reported in the second rows of Tables 2 and 3 are derived from the same sources as those reported in Table 1. 
1. Set in accordance with other parameters to satisfy the Keynesian stability condition.

2. Based on production workers accounting for 80 per cent of total employment. See (Mishel et al., 2007, p.118).

3. Set in accordance with $\pi=1-(1+\alpha \varphi) \omega^{\omega} p$.

4. Set in accordance with other parameters to yield capacity utilization rate of approximately 80 per cent.

5. See data.worldbank.org.

Table 2: Sustainability of Growth in Two Growth Regimes I

\begin{tabular}{lcccccccc}
\hline & $\omega_{r}$ & $\omega_{p}$ & $\pi$ & $\eta$ & $d_{R 1}$ & $d_{R 2}$ & $d_{R^{\max }}$ & $c$ \\
\hline Neoliberal & 0.23835 & 0.42 & 0.34165 & 21.72 & 1.327 & -1.218 & 0.262 & -0.043 \\
Golden Age & 0.2304 & 0.48 & 0.2896 & 2.92 & -0.446 & -2.442 & 0.088 & 0.025 \\
\hline
\end{tabular}

Table 3: Sustainability of Growth in Two Growth Regimes II

\begin{tabular}{lcccccccc}
\hline & $\omega_{\boldsymbol{r}}$ & $\omega_{p}$ & $\pi$ & $\eta$ & $d_{R 1}$ & $d_{R 2}$ & $d_{R^{\max }}$ & $c$ \\
\hline Neoliberal & 0.23835 & 0.42 & 0.34165 & 21.72 & 0.740 & 13.845 & 7.085 & 0.305 \\
Golden Age & 0.2304 & 0.48 & 0.2896 & 2.92 & -0.104 & 9.685 & 3.106 & 0.154 \\
\hline
\end{tabular}

\section{Conclusion}

Following Dutt (2005, 2006, 2008), Hein (2012), and Kim (2012), this paper extends a basic Kaleckian growth model to incorporate consumption emulation and borrowing behavior by working households. Particular attention is paid to the precise manner in which debtor households service their debts and its impact on the sustainability of growth in light of actually observed increases in income inequality.

The results suggest that the treatment of debt servicing as either a deduction from income or a household expense that is accommodated by sacrificing savings has a decisive effect on the sustainability of the Neoliberal growth regime. Specifically, the susceptibility of the latter to the substantial increases in income inequality that accompanied the transition from the Golden Age to the Neoliberal era depends on the precise debt servicing behavior of working households. This, in turn, suggests that as a microcosm of "financialized" capitalism, household debt servicing behavior warrants more extensive study in Post-Keynesian macrodynamics. 


\section{References}

Barba, Aldo and Massimo Pivetti (2009). "Rising household debt: Its causes and macroeconomic implications-a long-period analysis." Cambridge Journal of Economics 33(1), 113-137. crossref http://dx.doi.org/10.1093/cje/ben030

Bunting, David (1998). "Distributional basis of aggregate consumption." Journal of Post Keynesian Economics 20(3), 389-413.

Cynamon, Barry Z. and Steven M. Fazzari (2008). "Household debt in the consumer age: Source of growth - risk of collapse." Capitalism and Society 3(2), Article 3.

crossrefhttp://dx.doi.org/10.2202/1932-0213.1037

Dutt, Amitava K. (2005). “Consumption, debt and growth.” In Mark Setterfield, ed., Interactions in Analytical Political Economy, pp. 155-78. Armonk, NY: M.E. Sharpe.

Dutt, Amitava K. (2006). "Maturity, stagnation and debt: a Steindlian approach." Metroeconomica 57, 339-364. crossrefhttp://dx.doi.org/10.1111/j.1467-999X.2006.00246.x

Dutt, Amitava K. (2008). "The dependence effect, consumption and happiness: Galbraith revisited." Review of Political Economy 20(4), 527-550.

crossrefhttp://dx.doi.org/10.1080/09538250802308919

Hein, Eckhard (2012). The Macroeconomics of Finance-dominated Capitalism - and its Crisis. Cheltenham, UK: Edward Elgar. crossrefhttp://dx.doi.org/10.4337/9781781009161

Kim, Yun K (2012). "Emulation and consumer debt: Implications of keeping-up with the jones.” Working Paper 1208, Trinity College Working Paper Series.

Lavoie, Marc and Wynne Godley (2001-02). "Kaleckian models of growth in a coherent stock-ow monetary framework." Journal of Post Keynesian Economics 24(2), 277-311.

Levine, Adam Seth, Robert H. Frank, and Oege Dijk (2010). "Expenditure cascades." http://ssrn.com/abstract=1690612.

Mishel, Lawrence, Jared Bernstein, and Sylvia Allegretto (2007). The State of Working America 2006/2007. Ithaca, NY: Cornell University Press.

Mishel, Lawrence and Natalie Sabadish (2012, May). "CEO pay and the top 1 percent: how executive compensation and financial-sector pay have fueled income inequality." Issue brief 331, Economic Policy Institute.

Mohun, Simon (2006). "Distributive shares in the US economy, 1964-2001." Cambridge Journal of Economics 30(3), 347-370. crossrefhttp://dx.doi.org/10.1093/cje/bei065

Palley, Thomas I. (2002). "Economic contradictions coming home to roost? does the us economy face a long-term aggregate demand generation problem?" Journal of Post Keynesian Economics 25, 9-32.

Palley, Thomas I. (2013). "The middle class in macroeconomics and growth theory: a three class neo-kaleckian-goodwin model." Paper presented at the Meetings of the Eastern Economic Association, New York, May 2013. 
Ravina, Enrichetta (2007). "Habit formation and keeping up with the Joneses: evidence from micro data." http://ssrn.com/abstract=928248.

Setterfield, Mark (2013). "Wages, demand and us macroeconomic travails: Diagnosis and prognosis." In Steve M. Fazzari Cynamon, Barry Z. and Mark Setterfield, eds., After the Great Recession: The Struggle for Economic Recovery and Growth, pp. 158-184. Cambridge University Press.

Setterfield, Mark and Andrew Budd (2011). "A Keynes-Kalecki model of cyclical growth with agent-based features." In Philip Arestis, ed., Microeconomics, Macroeconomics and Economic Policy: Essays in Honour of Malcolm Sawyer, pp. 228-50. London: Palgrave Macmillan.

Setterfield, Mark and Yun K. Kim (2013). "Debt servicing, aggregate consumption, and growth." Trinity College Department Of Economics Working Paper 13-16.

Setterfield, Mark, Yun K Kim, and Jeremy Rees (2014). "Inequality, debt servicing, and the sustainability of steady state growth." Mimeo.

Skott, Peter and Soon Ryoo (2008). "Macroeconomic implications of financialization." Cambridge Journal of Economics 32(?), 827-862. crossrefhttp://dx.doi.org/10.1093/cje/ben012

Stockhammer, Engelbert (1999). "Robinsonian and kaleckian growth. an update on post- keynesian growth theories." Working Paper 67, Vienna University of Economics and Business Administration. http://ideas.repec.org/p/wiw/wiwwuw/wuwp067.html.

Wisman, Jon D. (2013). "Wage stagnation, rising inequality and the financial crisis of 2008." Cambridge Journal of Economics 37, 921-945. crossrefhttp://dx.doi.org/10.1093/cje/bes085 